\title{
The prevalence of abnormal echocardiographic findings in a sample of urban adult population
}

\author{
Grzegorz Kopeć1, Bartosz Sobień ${ }^{1}$, Mateusz Podolec ${ }^{2}$, Marcin Waligóra ${ }^{1}$, Mateusz Brózda ${ }^{1}$, \\ Joanna Zarzecka ${ }^{3}$, Bartłomiej Loster ${ }^{3}$, Jadwiga Nessler², Andrzej Pająk ${ }^{4}$, Piotr Podolec ${ }^{1}$ \\ 'Department of Cardiac and Vascular Diseases, Jagiellonian University, Medical College, John Paul II Hospital, Krakow, Poland \\ ${ }^{2}$ Department of Coronary Artery Disease, Jagiellonian University, Medical College, John Paul II Hospital, Krakow, Poland \\ ${ }^{3}$ Institute of Dentistry, Jagiellonian University, Medical College, Krakow, Poland \\ ${ }^{4}$ Department of Epidemiology and Population Studies, Institute of Public Health, Faculty of Health Sciences, Jagiellonian University, \\ Medical College, Krakow, Poland
}

\begin{abstract}
A bstract
Background: Echocardiography has emerged as the test of choice for the evaluation of cardiac diseases.

Aim: To assess the prevalence of a spectrum of cardiac abnormalities detected by echocardiography in a representative sample of an urban adult population.

Methods: Transthoracic echocardiography was performed in a random sample of 511 men (47\%) and women (53\%) aged 48-76 years selected from population registers in Krakow. Body surface area (BSA) was used to adjust echocardiographic parameters for variations in body size. Disease history and cardiovascular risk factors were assessed in all patients.

Results: Men smoked more frequently than women and had higher blood pressure and triglycerides and lower high density lipoprotein cholesterol. The most common finding was increased left ventricular (LV) end-diastolic diameter (EDd) (37\%), followed by mitral (32\%), aortic (24\%), or tricuspid (17\%) regurgitations, LV posterior wall (24.1\%) and interventricular septum (17.5\%) thickening, increased indexed LVEDd (23\%), increased left atrial diameter (LAd; $15.7 \%)$, reduced LV ejection fraction (LVEF; $15.3 \%)$, segmental wall motion abnormalities (13.9\%), increased indexed LAd (8.8\%), dilation of the ascending aorta (8\%), enlargement of the right ventricle (RV) $(2 \%)$ and elevation of RV systolic pressure $(0.6 \%)$. When adjusted for main cardiovascular risk factors and the presence of coronary artery disease, male sex was associated with a higher prevalence of enlargement of LV (LVEDd/BSA): OR = 1.8 (1.1-2.9), dilation of ascending aorta (aortic diameter/BSA): OR = 2.7 (1.3-5.8), and LA (LA/BSA) = OR 2.7 (1.3-5.6), as well as a decrease of LVEF: OR = 3.6 (1.9-6.5).

Conclusions: Approximately a quarter of urban adults aged 48 to 76 can be expected to have some abnormalities on echocardiographic examination. Some of these abnormalities such as aortic dilation, LA enlargement, LV enlargement and decreased LVEF are more frequently found in males than in females, even after adjustment for BSA, main cardiovascular disease risk factors, and the presence of coronary artery disease. The use of raw instead of indexed LAd and LVEDd overestimates the prevalence of LA and LV enlargement.
\end{abstract}

Key words: community-based study, echocardiography, general population, pulmonary hypertension

Kardiol Pol 2014; 72, 1: 42-49

\section{INTRODUCTION}

Echocardiography has emerged as the test of choice for the evaluation of cardiac diseases [1]. It provides a comprehensive assessment of cardiac chambers and great vessels dimensions, left (LV) and right (RV) ventricular function, pericardial disease, and valvular heart disease. Abnormalities found on echo- cardiographic study, even in patients without overt cardiac disease, are poor prognostic factors and prompt therapeutic implications [2].

Previous studies on the prevalence of cardiac abnormalities in the community concentrated usually on specific populations $[3,4]$ such as elderly subjects or focused on

\section{Address for correspondence:}

Grzegorz Kopeć, MD, PhD, Department of Cardiac and Vascular Diseases, Jagiellonian University, Medical College, John Paul II Hospital, ul. Prądnicka 80, 31-202 Kraków, Poland, e-mail: gkopec@szpitaljp2.krakow.pl Received: 24.01.2013 Accepted: 18.06.2013 
only single cardiac abnormalities such as LV dysfunction or hypertrophy $[2,5]$. Yet the prevalence of diverse echocardiographic abnormalities in the general adult population remains poorly known.

Therefore, in this cross-sectional study using echocardiography we aimed to assess the prevalence of a spectrum of cardiac abnormalities in representatives of an urban adult population.

\section{METHODS \\ Study population}

Data was collected from a sub-sample of participants of the Polish part of the Health, Alcohol and Psychosocial factors In Eastern Europe (HAPIEE) study. The original sample at baseline included men and women aged 45 to 69 randomly selected from an urban population registry in Krakow which has been described in detail previously $[6,7]$. In short, between 2 December 2008 and 28 May 2009, we telephoned 1,959 randomly selected participants of the HAPIEE study to invite them to the out-patient clinic for additional tests and interviews. A maximum of three calls were made to every participant. In cases of no response, a letter of invitation was sent. Contact was made with 1,555 (79\%) persons and 942 came to the clinic and were interviewed, so the response rate was $48 \%$. To characterise the study group, every patient was asked about: age, history of coronary artery disease (CAD) and acute myocardial infarction (AMI), and the presence of other main cardiovascular disease (CVD) risk factors such as: smoking, diabetes, hypertension, hypercholesterolaemia, and drugs used. Additionally, in every patient, a fasting lipid profile consisting of total cholesterol (TC), low density lipoprotein cholesterol (LDL-C), high density lipoprotein cholesterol (HDL-C), and triglycerides and blood pressure were assessed as recommended [8, 9]. Height and weight were measured to calculate body mass index (BMI) as follows: $\mathrm{BMI}=$ weight $[\mathrm{kg}] /$ height $[\mathrm{m}]^{2}$ and body surface area (BSA) as follows: $\mathrm{BSA}=[$ height $(\mathrm{cm}) \times$ weight $(\mathrm{kg})] / 3,600)^{1 / 2}[10]$. Obesity was defined as BMI $\geq 30 \mathrm{~kg} / \mathrm{m}^{2}$ [11]. Smoking status was defined as a current smoker (smoked at least once during the past month) or a non-current smoker. Transthoracic echocardiography (TTE) was performed in the first 523 consecutive participants of the study. This study complied with the Declaration of Helsinki, the institutional ethics committee approved the study protocol, and informed consent was obtained from each participant.

\section{Echocardiography}

A Vivid i (GE Healthcare) ultrasound machine, equipped with 2.5-5.0 MHz probe was used for the echocardiographic evaluation. Optimal standard views were obtained in patients in the steep left-lateral decubitus position with the patient's left arm raised. Every measurement was taken three times and averaged. Echo examinations were made and then analysed by three experienced echocardiographers. The following parameters were measured for the purpose of the study: left ventricular end-diastolic diameter (LVEDd), left ventricular end-systolic diameter (LVESd), left ventricular ejection fraction (LVEF), interventricular septal end-systolic (IVSESd) and end-diastolic (IVSEDd) diameter, left ventricular posterior wall diameter (LVPWd) at end-diastole (LVPWEDd) and end-systole (LVPWESd), left atrial diameter (LAd), aortic diameter (AOd), right ventricular diameter ( $R V d)$, mitral valve systolic $(M V s)$ and mean $(\mathrm{MVm})$ gradient and aortic valve (AoVs) systolic and mean (AoVm) gradient. Colour flow imaging was used to assess the presence of mitral (MR), tricuspid (TR), and aortic (AR) regurgitation. End-diastole and end-systole were defined as the frame in the cardiac cycle in which the cardiac dimension was the largest and the smallest, respectively [1]. According to the guidelines, dimensions of the LV, LA, and AO were additionally indexed for BSA [1].

LVEDd and LVESd, IVSd, and LVPWd were measured from the parasternal long axis view using 2D-targeted M-mode echocardiography at the level of the mitral valve leaflet tips. LVEF was calculated using the biplane method of discs (modified Simpson's rule). Regional wall motion abnormalities were diagnosed when hypokinesis, akinesis or dyskinesis of LV free wall or IVS was detected. LAd was measured using M-mode obtained from the parasternal long axis view from the trailing edge of the posterior aortic wall to the leading edge of the posterior LA wall at the ventricular end-systole when the LA chamber is at its greatest dimension. AOd was measured at the level of sinotubular junction in 2D parasternal long axis view using the leading edge to leading edge technique.

Right ventricle was measured at the proximal portion of the RV outflow tract from the parasternal window at end-diastole using the long axis view.

Aortic valve stenosis was defined as systolic aortic gradient $\geq 25 \mathrm{~mm} \mathrm{Hg}$ and mitral valve stenosis as mean mitral gradient $\geq 5 \mathrm{~mm} \mathrm{Hg}$. Dilation of ascending aorta was defined as $A O d \geq 36 \mathrm{~mm}$ or $\geq 21 \mathrm{~mm} / \mathrm{m}^{2}$. Enlargement of the RV was defined as RV diastolic diameter (RVDd) $\geq 33 \mathrm{~mm}$.

Doppler signal of tricuspid regurgitant wave velocity ( $v$ ) was used to estimate RV systolic pressure (RVSP) which was calculated as $4 \times v^{2}+$ estimated right atrial pressure and expressed in $\mathrm{mm} \mathrm{Hg}$. Right atrial pressure was estimated based on the measurement of the diameter of vena cava inferior and its changes during inspiration according to the guidelines [12].

To assess the prevalence of cardiac abnormalities, parameters such as LVEF, LVEDd, IVSEDd, LVPWEDd, and LAd, we classified into the four categories: normal, mildly abnormal, moderately abnormal, and severely abnormal in accordance with the European Society of Cardiology guidelines (Table 1) [1]. Other parameters were classified as normal or abnormal (outside the reference range) without further qualifying the degree of abnormality. As previously described [13], mitral 
Table 1. Classification of echocardiographic parameters based on a degree of abnormality according to the European Society of Cardiology [1]

\begin{tabular}{|c|c|c|c|c|c|c|c|c|}
\hline \multirow[t]{3}{*}{ Variable } & \multicolumn{4}{|c|}{ Women } & \multicolumn{4}{|c|}{ Men } \\
\hline & \multirow{2}{*}{$\begin{array}{c}\text { Reference } \\
\text { range }\end{array}$} & \multicolumn{3}{|c|}{ Abnormal } & \multirow{2}{*}{$\begin{array}{c}\text { Reference } \\
\text { range }\end{array}$} & \multicolumn{3}{|c|}{ Abnormal } \\
\hline & & Mildly & Moderately & Severely & & Mildly & Moderately & Severely \\
\hline LVEDd $[\mathrm{mm}]$ & $39-53$ & $54-57$ & $58-61$ & $\geq 62$ & $42-59$ & $60-63$ & $64-68$ & $\geq 69$ \\
\hline LVEDd/BSA $\left[\mathrm{mm} / \mathrm{m}^{2}\right]$ & $24-32$ & $33-34$ & $35-37$ & $\geq 38$ & $22-31$ & $32-34$ & $35-36$ & $\geq 37$ \\
\hline $\mathrm{LAd}[\mathrm{mm}]$ & $27-38$ & $39-42$ & $43-46$ & $\geq 47$ & $30-40$ & $41-46$ & $47-52$ & $\geq 52$ \\
\hline $\mathrm{LAd} / \mathrm{BSA}\left[\mathrm{mm} / \mathrm{m}^{2}\right]$ & $15-23$ & $24-26$ & $27-29$ & $\geq 30$ & $15-23$ & $24-26$ & $27-29$ & $\geq 30$ \\
\hline LVEF [\%] & $\geq 55$ & $45-54$ & $30-44$ & $<30$ & $\geq 55$ & $45-54$ & $30-44$ & $<30$ \\
\hline IVSEDd [mm] & $0.6-0.9$ & $1.0-1.2$ & $1.3-1.5$ & $\geq 1.6$ & $0.6-1.0$ & $1.1-1.3$ & $1.4-1.6$ & $\geq 1.7$ \\
\hline LVPWEDd [mm] & $0.6-0.9$ & $1.0-1.2$ & $1.3-1.5$ & $\geq 1.6$ & $0.6-1.0$ & $1.1-1.3$ & $1.4-1.6$ & $\geq 1.7$ \\
\hline
\end{tabular}

BSA — body surface area; IVSEDd — interventricular septum end-diastolic diameter; LAd — left atrial diameter; LVEDd — left ventricular end-diastolic diameter; LVEF — left ventricular ejection fraction; LVPWEDd — left ventricular posterior wall end-diastolic diameter

and tricuspid valvular regurgitation was diagnosed when more than trace regurgitation (within $1 \mathrm{~cm}$ of valve) was found, and aortic regurgitation was diagnosed in the presence of any regurgitant jet. No further quantifying of the degree of valves insufficiencies was made.

\section{Statistical analysis}

Statistical analysis was performed with Statistica PL software [StatSoft, Inc. (2010). STATISTICA (data analysis software system), version 9.1, Tulsa, OK, USA www.statsoft.com] and MedCalc version 11.6.1.0 (MedCalc Software, Mariakerke, Belgium). Continuous variables were reported using median and interquartile range $(\mathrm{IQR})$, categorical variables were described as counts and percentages. Continuous variables were compared using the Mann Whitney U-test. The $\chi^{2}$-test was used to compare categorical variables. Using logistic regression analysis, we adjusted the association between sex and cardiac abnormalities for age $(<$ median value $=0, \geq$ median value $=1$ ), and the presence of hypertension, hypercholesterolaemia, obesity, CAD, diabetes, and current smoking. All tests were two-sided and the significance level was set at $p<0.05$.

\section{RESULTS}

\section{Group characteristics}

We enrolled in this study 523 participants who were between 48 and 76 years of age, but further analyses were made in $511(98 \%)$ in whom good quality images were obtained. The clinical characteristics of the study population with the prevalence of main CVD risk factors are summarised in Table 2. Men ( $n=238$ ) accounted for $47 \%$ of the total population. As compared to women, they had higher blood pressure and triglycerides, and lower HDL-C. Smoking was more frequently declared by males than females. Age and distribution of other main CVD risk factors as well as cardiovascular therapies were similar in men and in women.

\section{Echocardiographic parameters}

Echocardiographic parameters in men and in women of the study population are shown in Table 3. Men had larger indexed LVEDd, LVESd, LAd, AOd, and RVd than women as they had thicker IVS and LVPW and lower gradient through the mitral valve.

\section{Prevalence of cardiac abnormalities}

The prevalence of LA and LV enlargement, IVS and LVPW thickening, and decrease of LVEF are shown in Table 4. Segmental wall motion abnormalities of LV myocardium were found in $71(13.9 \%)$ patients. Dilation of ascending aorta when defined as $\mathrm{AOd} \geq 36 \mathrm{~mm}$ was found in 42 (8\%) patients and when defined as AOd $\geq 21 \mathrm{~mm} / \mathrm{m}^{2}$ in $32(6 \%)$ study subjects. RV was enlarged in $10(2 \%)$ patients. MR, AR and TR were found in 164 (32\%), 124 (24\%) and 85 (17\%) participants, respectively. MVm gradient $\geq 5 \mathrm{~mm} \mathrm{Hg}$ was found in $4(0.8 \%)$ subjects and AoVs gradient $\geq 25 \mathrm{~mm} \mathrm{Hg}$ was found in $2(0.4 \%)$ patients. In most patients, the TR was small and therefore a good quality Doppler signal of the TR (as defined by well defined borders and dense spectral profile) was attained only in 33 patients. In all these patients, inferior vena cava diameter was less than $21 \mathrm{~mm}$. Therefore, right atrial pressure was assumed to be $5 \mathrm{~mm} \mathrm{Hg}$. An elevated RVSP $\geq 36 \mathrm{~mm} \mathrm{Hg}$ was found in only three $(0.6 \%)$ patients. The first patient was a 68-year-old man after MI, with LVEDd of $67 \mathrm{~mm}$, LAd of $56 \mathrm{~mm}$ and RVd of $32 \mathrm{~mm}$. The second patient was a 75-year-old male with reduced LVEF of $40 \%$, a history of CAD, LVEDd of $67 \mathrm{~mm}$, LAd of $55 \mathrm{~mm}$ and $\mathrm{RVd}$ of $34 \mathrm{~mm}$. The third patient was a 65 -year-old male with hypertension and normal LVEF, and significant thickening of IVSDd of $13 \mathrm{~mm}$ and LVPWDd of $12 \mathrm{~mm}$ and LAd of $49 \mathrm{~mm}$.

\section{Echocardiographic findings in men and women}

As shown in Table 4, men more frequently than women had enlarged LV and LA, decreased LVEF, and thickened IVS. 
Table 2. Group characteristics

\begin{tabular}{|c|c|c|c|c|}
\hline Variable & All & Men $(n=238)$ & Women $(n=273)$ & $\mathbf{P}$ \\
\hline Age [years] & $63.0(57.0-69.0)$ & $64.0(57.0-69.0)$ & $63.0(57.0-69.0)$ & 0.48 \\
\hline $\mathrm{BSA}\left[\mathrm{m}^{2}\right]$ & $1.8(1.7-2.0)$ & $1.8(1.7-2.0)$ & $1.7(1.7-1.9)$ & 0.98 \\
\hline $\mathrm{SBP}[\mathrm{mm} \mathrm{Hg}]$ & $136.0(123.5-149.5)$ & $138.3(128.0-151.3)$ & $131.5(118.5-148.0)$ & $<0.001$ \\
\hline $\mathrm{DBP}[\mathrm{mm} \mathrm{Hg}]$ & $86.0(78.0-93.5)$ & $88.5(80.0-94.5)$ & $83.3(77.0-92.5)$ & $<0.001$ \\
\hline $\mathrm{TC}[\mathrm{mmol} / \mathrm{l}]$ & $5.7(5.1-6.5)$ & $5.7(5.0-6.4)$ & $5.7(5.1-6.6)$ & 0.09 \\
\hline LDL-C [mmol/L] & $3.5(2.9-4.2)$ & $3.6(2.9-4.1)$ & $3.5(3.0-4.3)$ & 0.86 \\
\hline $\mathrm{HDL}-\mathrm{C}[\mathrm{mmol} / \mathrm{L}]$ & $1.4(1.2-1.7)$ & $1.3(1.1-1.5)$ & $1.5(1.3-1.8)$ & $<0.001$ \\
\hline Triglycerides [mmol/L] & $1.4(1.0-1.9)$ & $1.5(1.1-2.1)$ & $1.3(1.0-1.8)$ & 0.001 \\
\hline BMI $\left[\mathrm{kg} / \mathrm{m}^{2}\right]$ & $27.9(24.9-30.9)$ & $28.1(25.6-30.6)$ & $27.7(24.6-31.2)$ & 0.61 \\
\hline Hypertension & $273(53)$ & $127(53)$ & $146(53)$ & 0.95 \\
\hline Diabetes mellitus & $92(18)$ & $50(21)$ & $42(15)$ & 0.12 \\
\hline Obesity & $127(25)$ & $57(24)$ & $70(26)$ & 0.73 \\
\hline Hypercholesterolaemia & $241(47)$ & $105(44)$ & $136(50)$ & 0.23 \\
\hline Smoking & $102(20)$ & $60(25)$ & $42(15)$ & 0.006 \\
\hline$C A D$ & $132(26)$ & $55(23)$ & $77(28)$ & 0.23 \\
\hline History of Ml & $40(8)$ & $24(10)$ & $16(6)$ & 0.11 \\
\hline Beta-blocker & $156(30.5)$ & $71(30)$ & $85(31)$ & 0.82 \\
\hline ACEI & $147(29)$ & $73(31)$ & $74(27)$ & 0.96 \\
\hline Calcium channel blocker & $71(14)$ & $33(14)$ & $38(14)$ & 0.91 \\
\hline ARB & $37(7)$ & $15(6)$ & $22(8)$ & 0.60 \\
\hline Diuretics & $96(19)$ & $46(19)$ & $50(18)$ & 0.86 \\
\hline Statins & $112(22$ & $54(23)$ & $58(21)$ & 0.77 \\
\hline Fibrates & $8(1.6)$ & $3(1.3)$ & $5(1.8)$ & 0.87 \\
\hline ASA & $109(21)$ & $55(23)$ & $54(20)$ & 0.42 \\
\hline
\end{tabular}

Data is expressed as median (interquartile range)/n (\%); ACEI — angiotensin converting enzyme inhibitor; ARB — angiotensin receptor blocker; ASA — acetylsalicylic acid; BMI — body mass index; BSA — body surface area; CAD — coronary artery disease; DBP — diastolic blood pressure; HDL-C — high density lipoprotein cholesterol; LDL-C — low density lipoprotein cholesterol; MI — myocardial infarction; SBP — systolic blood pressure; TC — total cholesterol

Additionally, dilation of ascending $\mathrm{AO}$ was more frequent in men than in women: $32(13 \%)$ vs. $10(3.7 \%)$, respectively, $\mathrm{p}<0.001$ when defined as $\mathrm{AOd} \geq 36 \mathrm{~mm}$, and $22(9 \%)$ vs. $10(4 \%)$, respectively, $p=0.01$ when defined as $\mathrm{AOd} \geq 21 \mathrm{~mm} / \mathrm{m}^{2}$. RV was enlarged in a similar proportion of men (eight; $3.4 \%$ ) and women (two; 0.7\%) women, $\mathrm{p}=0.07$.

$M R, A R$ and $T R$ were found in a similar proportion of women and men: 92 (34\%) vs. 72 (30\%), p = 0.4; 61 (22\%) vs. $63(26 \%), p=0.3$; and $45(16 \%)$ vs. $40(17 \%), p=0.8$, respectively.

When adjusted for main cardiovascular risk factors, male sex was associated with a higher prevalence of the following echocardiographic abnormalities: decrease of LVEF $<55 \%$ $(\mathrm{OR}=3.6 ; \mathrm{Cl} 1.9-6.5 ; \mathrm{p}<0.001)$, increase of LAd/BSA $(\mathrm{OR}=2.7 ; \mathrm{Cl} 1.3-5.6 ; \mathrm{p}<0.001)$, increase of LVEDd/BSA $(\mathrm{OR}=1.8 ; \mathrm{Cl} 1.1-2.9 ; \mathrm{p}<0.001)$, and increase of AOd/BSA (OR 2.7; Cl 1.3-5.8; $\mathrm{p}<0.001)$.

\section{DISCUSSION}

In this cross-sectional analysis of a sample of urban adults aged 48 to 76 years, we have presented the prevalence of major cardiac abnormalities detected by TTE.

The most common finding was increased LVEDd (37\%), followed by MR (32\%), AR (24\%), or TR (17\%), LV posterior wall $(24.1 \%)$ and IVS (17.5\%) thickening, increased indexed LVEDd (23\%), increased LAd (15.7\%), reduced LVEF (15.3\%), segmental wall motion abnormalities (13.9\%), increased indexed LAd (8.8\%), dilation of the ascending aorta (8\%), enlargement of RV (2\%) and elevation of RVSP (0.6\%). We have also shown that male sex was associated with a higher prevalence of LV, AO and LA enlargement, and with decreased LVEF, irrespective of other cardiovascular risk factors and the presence of CAD.

Although our study is based on a randomly selected urban population, we did not aim to conclude on the reference values of echocardiographic parameters. This resulted from 
Table 3. Echocardiographic data in the studied population

\begin{tabular}{|c|c|c|c|c|}
\hline Variable & All & Men & Women & $\mathbf{P}$ \\
\hline LVEF [\%] & $62.0(55.0-68.0)$ & $60.0(55.0-69.0)$ & $63.0(58.0-66.0)$ & 0.12 \\
\hline LVEDd [mm] & $49.6(43.0-57.0)$ & $53.0(46.0-59.0)$ & $48.0(41.0-55.0)$ & $-{ }^{*}$ \\
\hline LVEDd/BSA [mm/m²] & $27.5(23.0-31.7)$ & $28.6(24.8-32.8)$ & $25.4(22.3-30.3)$ & $<0.001$ \\
\hline LVESd [mm] & $33.4(27.0-39.7)$ & $35.0(21.0-55.0)$ & $32.0(26.0-39.0)$ & - \\
\hline LVESd/BSA [mm/m²] & $18.0(14.7-21.6)$ & $19.2(15.9-22.3)$ & $17.0(13.9-20.7)$ & $<0.001$ \\
\hline IVSEDd [mm] & $9.0(8.0-10.4)$ & $9.4(8.2-10.7)$ & $9.0(7.5-10.0)$ & $<0.001$ \\
\hline IVSESd [mm] & $14.0(13.0-16.2)$ & $15.0(13.0-17.0)$ & $14.0(12.1-16.0)$ & 0.002 \\
\hline LVPWEDd [mm] & $9.5(8.2-10.9)$ & $10.0(9.0-11.0)$ & $9.2(8.0-10.4)$ & 0.003 \\
\hline LVPWESd [mm] & $14.3(12.6-16.4)$ & $14.5(12.7-17.0)$ & $14.0(12.0-16.0)$ & 0.02 \\
\hline LAd [mm] & $34.5(31.0-38.0)$ & $36.3(32.3-39.3)$ & $33.5(30.2-37.0)$ & - \\
\hline LAd/BSA [mm/m²] & $18.6(16.5-21.2)$ & $19.3(17.4-22.0)$ & $18.0(15.8-20.4)$ & $<0.001$ \\
\hline $\mathrm{AOd}[\mathrm{mm}]$ & $31.0(28.0-33.0)$ & $32.0(30.0-35.0)$ & $29.0(27.0-32.0)$ & - \\
\hline $\mathrm{AOd} / \mathrm{BSA}\left[\mathrm{mm} / \mathrm{m}^{2}\right]$ & $16.7(14.7-18.6)$ & $17.4(15.7-19.0)$ & $16.0(13.7-17.8)$ & $<0.001$ \\
\hline $\mathrm{RVd}[\mathrm{mm}]$ & $24.2(22.0-27.0)$ & $25.7(23.0-28.0)$ & $23.8(21.5-26.0)$ & - \\
\hline $\mathrm{RVd} / \mathrm{BSA}\left[\mathrm{mm} / \mathrm{m}^{2}\right]$ & $13.2(11.5-14.8)$ & $13.8(12.1-15.4)$ & $12.7(11.1-14.1)$ & $<0.001$ \\
\hline AoVs [mm Hg] & $4.9(3.7-6.3)$ & $4.9(3.6-5.9)$ & $4.9(3.7-6.6)$ & 0.22 \\
\hline AoVm [mm Hg] & $2.4(1.8-3.1)$ & $2.3(1.8-3.0)$ & $2.4(1.8-3.1)$ & 0.43 \\
\hline MVs [mm Hg] & $3.0(2.4-3.9)$ & $2.9(2.2-3.9)$ & $3.5(2.5-3.9)$ & 0.04 \\
\hline $\mathrm{MVm}[\mathrm{mm} \mathrm{Hg}]$ & $1.2(0.9-1.6)$ & $1.2(0.9-1.5)$ & $1.3(1.0-1.6)$ & 0.03 \\
\hline
\end{tabular}

Data is expressed as median (interquartile range), *only indexed diameters of LV, LA and RV were compared; AOd — aortic diameter; AoVm — mean gradient through the aortic valve; AoVs — systolic gradient through the aortic valve; BSA — body surface area; IVSEDd — interventricular septum end-diastolic diameter; IVSESd — interventricular septum end-systolic diameter; LAd — left atrial diameter; LVEDd — left ventricular end-diastolic diameter; LVEF — left ventricular ejection fraction; LVESd — left ventricular end-systolic diameter; LVPWEDd — left ventricular posterior wall end-diastolic diameter; LVPWESd - left ventricular posterior wall end-systolic diameter; MVm — mean gradient through the mitral valve; MVs — systolic gradient through the mitral valve; RVd — right ventricular diameter

a high prevalence of CVD risk factors in the studied population. To describe the prevalence of a spectrum of cardiac abnormalities, we used reference values obtained from studies in so-called 'normal' subjects currently recommended by the European Society of Cardiology [1].

Enlargement of the LV was the most common cardiac abnormality detected in our study. We have also found that the mean LVEDd in the current study was higher than those reported in a previous community-based echocardiographic study [14] conducted in Denmark (mean LVEDd $48.4 \mathrm{~mm}$ in men and $44.2 \mathrm{~mm}$ in women). The latter study included 764 representatives of the general population with a similar age distribution (50-89 years) to our cohort, but with significantly lower prevalence of CVD risk factors such as hypertension or diabetes. We assume that different distribution of CVD risk factors may, at least partly, explain the observed differences in the LV diameter.

Similarly to previous works, we found that valvular regurgitation is highly prevalent in the adult population. In the Framingham Heart Study, colour Doppler echocardiography [13] was performed in 1,696 men and 1,893 women aged $54 \pm 10$ years. After excluding trace regurgitations, MR was diagnosed in $19 \%$ and TR in $17 \%$ of participants, while any
AR (including trace regurgitation) was found in $10.5 \%$ of participants. Furthermore, is was shown that the main predictors of MR were age, hypertension and increased $\mathrm{BMI}$, that the main predictors of TR were age, increased BMI and female gender, and that the main predictors of AR were age and male gender. We speculate that the characteristics of our population, namely older age, higher prevalence of hypertension and increased BMI, could explain the higher proportions of patients with valvular regurgitations in our population than in the population from the Framingham study.

An important element of our study is an estimation of the prevalence of elevated RVSP in a sample of the general adult population. According to the guidelines, RVSP $>36 \mathrm{~mm} \mathrm{Hg}$ makes a diagnosis of pulmonary hypertension $(\mathrm{PH})$ possible [15]. Based on this recommendation, we could suspect $\mathrm{PH}$ in $0.6 \%$ of our population. The characteristics of patients who had the increased RVSP suggested LV systolic and/or diastolic dysfunction as a main cause for this abnormality. Current knowledge on the prevalence of $\mathrm{PH}$ is mostly based on registries from reference $\mathrm{PH}$ centres which may underestimate the true prevalence of the disease in the community [16]. Accordingly, some groups have aimed to assess its true prevalence in the general population. An Australian group 
Table 4. Prevalence of cardiac abnormalities

\begin{tabular}{|c|c|c|c|c|c|c|}
\hline \multirow[t]{2}{*}{ Variable } & \multirow[t]{2}{*}{ Study subjects } & \multirow[t]{2}{*}{ Normal value } & \multicolumn{3}{|c|}{ Abnormal value } & \multirow[t]{2}{*}{$\mathbf{P}^{*}$} \\
\hline & & & Mildly & Moderately & Severely & \\
\hline \multirow[t]{3}{*}{ LVEF } & All & $433(84.7 \%)$ & 65 & 9 & 4 & \multirow{3}{*}{$<0.001$} \\
\hline & Males & $187(78.5 \%)$ & 42 & 7 & 2 & \\
\hline & Females & $246(90.1 \%)$ & 23 & 2 & 2 & \\
\hline LA & All & $431(84.3 \%)$ & 64 & 10 & 6 & \multirow{5}{*}{0.04} \\
\hline \multirow[t]{3}{*}{ LA/BSA } & All & $461(90.2 \%)$ & 38 & 10 & 2 & \\
\hline & Males & $202(84.9 \%)$ & 25 & 9 & 2 & \\
\hline & Females & $259(94.8 \%)$ & 13 & 1 & 0 & \\
\hline LVEDd & All & $323(63.2 \%)$ & 77 & 39 & 72 & \\
\hline \multirow[t]{3}{*}{ LVEDd/BSA } & All & $394(77.1 \%)$ & 64 & 13 & 40 & \multirow{3}{*}{0.01} \\
\hline & Males & $171(71.8 \%)$ & 39 & 7 & 21 & \\
\hline & Females & $223(81.7 \%)$ & 25 & 6 & 19 & \\
\hline \multirow[t]{3}{*}{ IVSEDd } & All & $416(82.5 \%)$ & 80 & 9 & 6 & \multirow{3}{*}{0.02} \\
\hline & Males & $183(76.9 \%)$ & 42 & 5 & 6 & \\
\hline & Females & $233(85.5 \%)$ & 38 & 4 & 0 & \\
\hline \multirow[t]{3}{*}{ LVPWEDd } & All & $392(76.7 \%)$ & 106 & 9 & 4 & \multirow{3}{*}{0.2} \\
\hline & Males & $176(33.9 \%)$ & 56 & 5 & 1 & \\
\hline & Females & $216(79.1 \%)$ & 50 & 4 & 3 & \\
\hline
\end{tabular}

*The $\mathrm{p}$ value is for the difference between the prevalence of abnormal and normal records in men and women; BSA — body surface area; IVSEDd - interventricular septum end-diastolic diameter; LAd — left atrial diameter; LVEDd — left ventricular end-diastolic diameter; LVEF — left ventricular ejection fraction; LVPWEDd — left ventricular posterior wall end-diastolic diameter

published recently the results of their retrospective analysis of a large echo database from a cohort of Armadale patients referred for echocardiographic examination to a central echo laboratory. They found PH (defined as RVSP > $40 \mathrm{~mm} \mathrm{Hg}$ ) in $9.1 \%$ of the referred patients, which corresponded to $0.3 \%$ of the general Armadale population [17]. A potential advantage of our study was the collection of echocardiographic data directly from a general adult population instead of extrapolation of data obtained from patients referred to echocardiographic examination for different reasons to the general population. The well known limitation of any echocardiographic study in the field of $\mathrm{PH}$ is that echocardiography can only be used to suspect, but not to diagnose, $\mathrm{PH}$ which in turn requires right heart catheterisation. Nevertheless, currently echocardiography is an established screening method in $\mathrm{PH}$ [15].

Cardiac geometry varies with body size. So, to adjust for this variation, echocardiographic variables have been standardised for anthropometric measures such as BSA [18]. Unfortunately, there is no consensus on the optimal adjustment [1]. Our data shows that this issue is clinically relevant since the use of raw instead of indexed LAd and LVEDd overestimated the prevalence of LA and LV enlargement.

\section{Limitations of the study}

The interpretation of the results of our study has some limitations. First, the studied group was selected from an urban population which has better access to medical services than the average in Poland. Second, despite putting a lot of effort into achieving a high participation rate, it was not high in the present study but similar to many other recent studies [19]. Earlier observations showed that participants in the HAPPIE study had lower total mortality than subjects who did not respond to invitation. Therefore, the study was done on a healthier part of the population [20]. This leaves a space for a selection bias, but the magnitude of it cannot be estimated because no population data based on echocardiographic findings has been published in Poland. Third, the population does not represent all adults but only urban residents in a defined range of age. Fourth, we did not report on all parameters which can be obtained from TTE, but only those readily obtained in most echo laboratories. Additionally, due to the screening nature of the study, we did not aim to quantify the severity of valve insufficiencies.

Our study has several strengths. First, we present previously unaddressed epidemiological data on a spectrum of cardiac abnormalities detected by echocardiography in a community. Second, we have shown the prevalence of elevated RVSP based on echocardiographic studies obtained in a randomly selected adult population. Third, evidence from our study may have great practical use since people of middle age and older who were included in our study account for the most frequently referred group for echocardiographic examination. 


\section{CONCLUSIONS}

Approximately a quarter of urban adults aged 48 to 76 can be expected to have some abnormalities on echocardiographic examination. Some of these abnormalities, such as aortic dilation, LA enlargement, LV enlargement and decreased LVEF, are more frequently found in males than in females even after adjustment for main CVD risk factors and the presence of CAD. The use of raw instead of indexed LAd and LVEDd overestimates the prevalence of LA and LV enlargement.

\section{Acknowledgements}

This research was supported by the Polish Ministry of Science and Higher Education.

\section{Conflict of interest: none declared}

\section{References}

1. Lang RM, Bierig M, Devereux RB et al. Recommendations for chamber quantification. Eur J Echocardiogr, 2006; 7: 79-108.

2. Redfield MM, Jacobsen SJ, Burnett JC Jr et al. Burden of systolic and diastolic ventricular dysfunction in the community: appreciating the scope of the heart failure epidemic. JAMA, 2003; 289: 194-202.

3. Leibowitz D, Stessman-Lande I, Jacobs J et al. Cardiac structure and function in persons 85 years of age. Am J Cardiol, 2011; 108: 465-470.

4. Yousaf F, Collerton J, Kingston A et al. Prevalence of left ventricular dysfunction in a UK community sample of very old people: the Newcastle 85+ study. Heart, 2012; 98: 1418-1423.

5. Mureddu GF, Agabiti N, Rizzello V et al. Prevalence of preclinical and clinical heart failure in the elderly. A population-based study in Central Italy. Eur J Heart Fail, 2012; 14: 718-729.

6. Kopec G, Sobien B, Podolec M et al. Knowledge of a patient-dependant phase of acute myocardial infarction in Polish adults: the role of physician's advice. Eur J Public Health, 2011; 21: 603-608.

7. Bobak M, Capkova N, Pajak A et al. The HAPIEE Study: a multi-centre study of determinants of cardiovascular diseases in Russia, Poland and the Czech Republic. Eur J Public Health, 2003; 13: 37-39.
8. Cybulska B, Szostak WB, Podolec P et al. PFP Editorial Board. Polish forum for prevention guidelines on dyslipidaemia. Kardiol Pol, 2008; 66: 1239-1242.

9. Tykarski A, Podolec P, Kopeć G et al. Polish Forum for Prevention Guidelines on arterial hypertension. Kardiol Pol, 2007; 65:1137-1141.

10. Mosteller RD: Simplified calculation of body surface area. NEngl J Med, 1987; 317: 1098.

11. Zahorska-Markiewicz B, Podolec P, Kopeć G et al. Polish Forum for Prevention Guidelines on overweight and obesity. Kardiol Pol, 2008; 66: 594-596.

12. Rudski LG, Lai WW, Afilalo J et al .Guidelines for the echocardiographic assessment of the right heart in adults: a report from the American Society of Echocardiography endorsed by the European Association of Echocardiography, a registered branch of the European Society of Cardiology, and the Canadian Society of Echocardiography. J Am Soc Echocardiogr, 2010; 23: 685-713.

13. Singh JP, Evans JC, Levy D et al. Prevalence and clinical determinants of mitral, tricuspid, and aortic regurgitation (the Framingham Heart Study). Am J Cardiol, 1999; 83: 897-902.

14. Raymond I, Pedersen F, Steensgaard-Hansen F et al. Prevalence of impaired left ventricular systolic function and heart failure in a middle aged and elderly urban population segment of Copenhagen. Heart, 2003; 89: 1422-1429.

15. Galiè N, Hoeper MM, Humbert $\mathrm{M}$ et al. Guidelines for the diagnosis and treatment of pulmonary hypertension. Eur Respir J, 2009; 34: 1219-1263.

16. Humbert M, Sitbon O, Chaouat A et al. Pulmonary arterial hypertension in France: results from a national registry. Am J Respir Crit Care Med, 2006; 173: 1023-1030.

17. Strange G, Playford D, Stewart $S$ et al. Pulmonary hypertension: prevalence and mortality in the Armadale echocardiography cohort. Heart, 2012; 98: 1805-1811.

18. Wild PS, Sinning CR, Roth A et al. Distribution and categorization of left ventricular measurements in the general population: results from the population-based Gutenberg Heart Study. Circ Cardiovasc Imaging, 2010; 3: 604-613.

19. Morton LM, Cahil J, Hartge P. Reporting participation in epidemiologic studies: a survey of Practice. Am JEpidemiol, 2006; 163:197-203.

20. Topór-Mądry R, Bobak M, Pająk A. 5-year mortality in respondents and non-respondents for the cohort study of 20000 randomly selected middle aged men and women. The HAPIEE PROJECT. EuroPrevent 2012, Dublin, Ireland, May 3-5, 2012, P405. 


\title{
Częstość występowania nieprawidłowości w badaniu echokardiograficznym w próbie dorosłej populacji wielkomiejskiej
}

\author{
Grzegorz Kopeć ${ }^{1}$, Bartosz Sobień ${ }^{1}$, Mateusz Podolec ${ }^{2}$, Marcin Waligóra ${ }^{1}$, Mateusz Brózda ${ }^{1}$, \\ Joanna Zarzecka ${ }^{3}$, Bartłomiej Loster ${ }^{3}$, Jadwiga Nessler², Andrzej Pająk ${ }^{4}$, Piotr Podolec ${ }^{1}$ \\ ${ }^{1}$ Klinika Chorób Serca i Naczyń, Uniwersytet Jagielloński, Collegium Medicum, Krakowski Szpital Specjalistyczny im. Jana Pawła II, Kraków \\ ${ }^{2}$ Klinika Choroby Wieńcowej, Instytut Kardiologii, Uniwersytet Jagielloński, Collegium Medicum, Krakowski Szpital Specjalistyczny \\ im. Jana Pawła II, Kraków \\ ${ }^{3}$ Instytut Stomatologii, Uniwersytet Jagielloński, Collegium Medicum, Kraków \\ ${ }^{4}$ Zakład Epidemiologii i Badań Populacyjnych, Instytut Zdrowia Publicznego, Wydział Nauk o Zdrowiu, Uniwersytet Jagielloński, \\ Collegium Medicum, Kraków
}

\section{Streszczenie}

Wstęp: Echokardiografia jest badaniem z wyboru w diagnostyce chorób serca.

Cel: Celem niniejszej pracy była ocena częstości występowania zmian w badaniu echokardiograficznym w losowej próbie populacji wielkomiejskiej.

Metody: Badanie echokardiograficzne przeprowadzono w losowej próbie 511 mężczyzn (47\%) i kobiet (53\%) w wieku 48-76 lat, wybranych z rejestrów ludności w Krakowie. Od wszystkich osób zebrano ujednolicony wywiad chorobowy. Oceniono profil czynników ryzyka i wykonano badanie echokardiograficzne przezklatkowe w sposób standardowy. Wybrane parametry echokardiograficzne standaryzowano na powierzchnię ciała (BSA) zgodnie z zaleceniami.

Wyniki: Mężczyźni w porównaniu z kobietami mieli wyższe ciśnienie tętnicze, większe stężenie triglicerydów i mniejsze stężenie cholesterolu frakcji HDL we krwi. W badaniu echokardiograficznym najczęściej stwierdzano zwiększenie średnicy końcoworozkurczowej lewej komory (LV): 37\%, a następnie niedomykalność zastawki mitralnej: 32\%, aortalnej: 24\%, trójdzielnej: 17\%, pogrubienie ściany tylnej LV: 24,1\% i przegrody międzykomorowej: 17,5\%, zwiększenie zindeksowanego wymiaru końcoworozkurczowego LV: 23\%, zwiększenie średnicy lewego przedsionka (LA): 15,7\%, zmniejszenie frakcji wyrzutowej LV (LVEF): 15,3\%, odcinkowe zaburzenia kurczliwości LV: 13,9\%, zwiększenie zindeksowanej średnicy LA: 8.8\%, poszerzenie aorty wstępującej: $8 \%$, powiększenie prawej komory (RV): $2 \%$ i zwiększenie szacowanego ciśnienia skurczowego w RV: 0,6\%. Po wystandaryzowaniu na główne czynniki ryzyka chorób sercowo-naczyniowych i obecność choroby niedokrwiennej serca u mężczyzn, w porównaniu z kobietami, częściej stwierdzano: powiększenie LV (wymiar późnorozkurczowy LV/BSA): $\mathrm{OR}=2,7(1,3-5,6)$, poszerzenie aorty (średnica aorty/BSA): OR = 2,7 (1,3-5,8) i LA (średnica LA/BSA): OR 2,7 (1,3-5,6) oraz zmniejszenie LVEF: OR = 3,6 (1,9-6,5).

Wnioski: U ok. 1/4 części dorosłej populacji wielkomiejskiej w wieku 48-76 lat można się spodziewać obecności co najmniej 1 nieprawidłowości w badaniu echokardiograficznym. Niektóre z nich, takie jak poszerzenie aorty wstępującej, powiększenie LA i LV oraz obniżenie LVEF występują częściej u mężczyzn niż u kobiet, nawet po uwzględnieniu wskaźnika masy ciała, podstawowych czynników ryzyka chorób sercowo-naczyniowych i obecności choroby niedokrwiennej serca. Wykorzystanie zmierzonych zamiast indeksowanych wielkości LA i LV przeszacowuje częstość występowania ich powiększenia w populacji. Słowa kluczowe: badanie populacyjne, echokardiografia, nadciśnienie płucne, populacja ogólna

Kardiol Pol 2014; 72, 1: 42-49

\section{Adres do korespondencji:}

dr n. med. Grzegorz Kopeć, Klinika Chorób Serca i Naczyń, Uniwersytet Jagielloński, Collegium Medicum, Krakowski Szpital Specjalistyczny im. Jana Pawła II, ul. Prądnicka 80, 31-202 Kraków, e-mail: gkopec@szpitaljp2.krakow.pl

Praca wpłynęła: 24.01.2013 r. Z Zaakceptowana do druku: 18.06.2013 r. $\quad$ Data publikacji AoP: 10.07.2013 r. 